\title{
PREDICTION POWER PROPULSION OF THE SHIP \\ AT THE STAGE OF PRELIMINARY DESIGN \\ Part I: FORECASTING METHOD FOR POWER PROPULSION \\ OF SHIP AT THE STAGE OF PRELIMINARY DESIGN
}

\author{
Tadeusz SZELANGIEWICZ, Katarzyna ŻELAZNY \\ Maritime University of Szczecin
}

\begin{abstract}
:
During the design of the ship the most important decisions are made at the stage of preliminary design. One of the most important design parameters assumed by the shipowner is its service speed in real weather conditions occurring in the shipping line. For this speed, at the stage of preliminary design, when are known only to the basic geometric parameters of the ship and its motor power should be determined. In practice, design, power propulsion is determined with a very approximate formulas but for the speed in calm water. Only after the project contract and the signing of the contract are carried out by means of resistance and self-propulsion of model test. The article presents the concept of the method for determining the power propulsion for the assumed service speed, which depends only on the basic geometric parameters of the ship's hull.
\end{abstract}

Key words: power propulsion, service speed, preliminary design

\section{INTRODUCTION}

Designing vessels, including cargo vessels it is reduced in the first instance to determine the basic main dimensions (length, breadth, draught, height side), displacement and block coefficient and, on the basis of fixed dimensions, the lines of hull of the ship. Further followed by: the power propulsion, the volume and surface of the hull, stability, freeboard, damage stability, seakeeping, range and autonomy and the cost of construction of the ship. All subsequent parameters of the designed ship and its properties depend on the basic main dimensions, which are set in the first (preliminary) design stage. The design process is performed iteratively, and thus it is divided into respective stages. Throughout the design process it is the most important preliminary stage (analysis of assumptions owner, development of the basic dimensions of the main development of the concept and preliminary design), because at this stage (Fig. 1):

- the designer has maximum flexibility in decisionmaking,

- however, knowledge of the planned ship is the smallest,

- although the cost of implementing this phase of the smallest, the consequences of possible errors are greatest.

So in order to, on the one hand to reduce the number of iterations leading to the optimal solution, and on the other reduce the possibility of errors in the operating project, developed mathematical models that are functions of certain properties or parameters of the designed ship dependent only on its basic dimensions of the major and most recently on the environmental conditions, which will be operated designed ship.

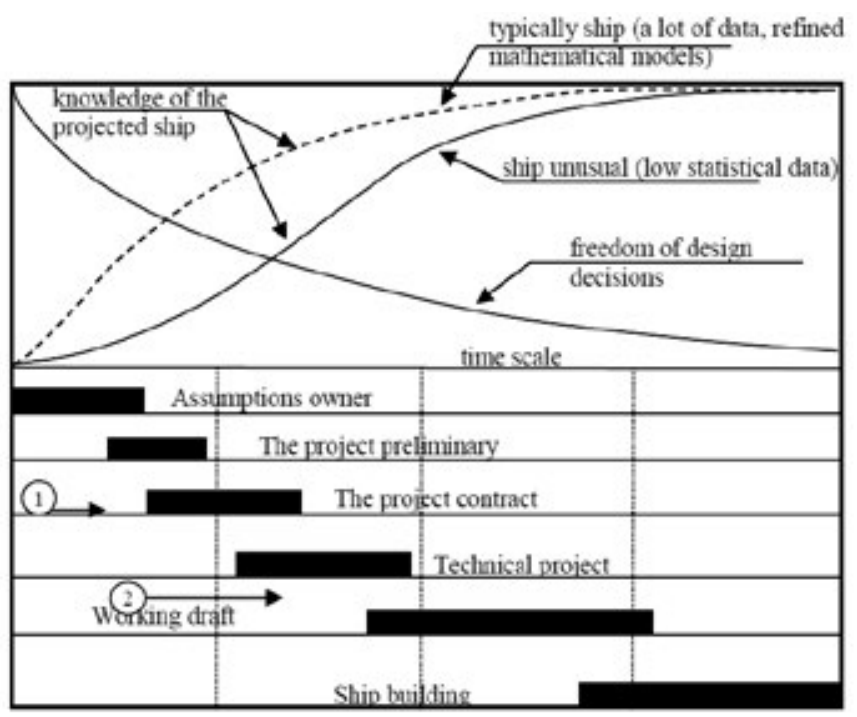

Fig. 1 The importance of the next stages of the design for the knowledge of the planned ship:

(1) - at this stage they should be defined dimensions of the vessel and the propulsion for the established service speed,

(2) - in the current design of ship resistance and propulsion power are determined after signing the contract, based on model tests of these studies and of the attached sea margin SM is calculated service speed

Source: Own study based on [2]. 
During design, the designer is looking for the optimal solution that meets the assumptions (requirements) of the owner, mainly established service speed and load capacity of the ship at the meeting the technical criteria (contained in certain regulations) such as buoyancy, stability, subdivision.

One of the major tasks carried out at the stage of preliminary design is to determine the power propulsion, at which the ship will be sailed by the owner of the assumed speed. Power propulsion, in addition to the predetermined speed, a crucial impact on the shape of the ship hull and propeller parameters - the geometry of the ship's hull and the propeller depends also on the overall efficiency of the drive, which should be as large as possible.

The aim of the design process is therefore the choice of the design parameters (eg. the basic dimensions of the main ship) to the result achieved, which is a project of the ship guarantee the achievement of the assumed speed of the assumed capacity and with the least power propulsion and ship construction costs. Then the owner can expect profits from the operation so designed ship.

The solution thus defined design task easier mathematical models containing compounds between the geometry of the hull and the propeller and service speed, power propulsion and weather conditions occurring on the shipping line, which is operated ship.

\section{THE SPEED AND POWER PROPULSION IN THE PROCESS OF SHIP DESIGN}

When designing strives to make technical object used for maritime transport which is the ship brought the shipowner expected profit from its operation. Thus, the design process, in addition to technical criteria included additional economic criteria [9]. Designed to determine whether the vessel will meet the expectations of the owner, especially economic measures serve to assess the design excellence of the ship. The most commonly used measures of evaluation are:

- the efficiency of transport $[5,6,10]$,

- design energy efficiency index (EEDI) IMO (in force since 01.01.2013) $[3,7,11]$,

- economic indicators [1].

In all these types of assessment measures, design excellence is the ship speed (openly or explicitly depend on other parameters occurring in these measures) and power propulsion. This means that the speed of the ship, assumed by the shipowner resulting from the drive power is one of the most important design parameters. From the ship's speed and power propulsion depends on fuel (which has an impact on the operating costs of the ship and any profit the owner), emissions (including $\mathrm{CO}_{2}$ and $\mathrm{NO}_{\mathrm{x}}$ ), the time of the cruise, and taking into account the safety, the shipping route. The speed of the ship is so important that it is written in the contract for the construction of the ship. If the ship was operated on calm water without waves and wind, is to develop a mathematical model to calculate the speed and power propulsion as a function of basic geometric parameters of the hull of the ship does not constitute any problem. However, the ship is operating at various shipping lines, which are variable, random parameters characterizing the wave and wind. Hence the development of a model service speed (and power propulsion) of the ship can attain in real weather conditions is a serious problem.
In the current design practice, assumed by the shipowner speed (also known as the contractual rate) is the speed of a ship in calm water - after the construction of the ship, the speed is measured in calm water and compared with the provisions of the contract. During the initial design, using very rough dependence is determined power propulsion for the design speed in calm water (this is equivalent to the speed of contract) - Fig. 1. Only after the draft contract and the signature of the contract (Fig. 1) are made model tests resistance and power propulsion on calm water (curve 1 in Fig. 2). Then, taking into account the sea margin SM (usually $15 \%$ ) is calculated by the nominal engine power $\mathrm{N}_{\mathrm{n}}$ and for the projected service speed $\mathrm{V}_{\mathrm{E}}$ (Fig. 2). Taken addition shipping does not allow either the precise actual service speed in real weather conditions occurring in the shipping line nor to determine the power propulsion to guarantee the achievement of the assumed service speed.

The method of estimating the operational speed based on model tests of resistance and power propulsion shown in Fig. 2, is widely used for cargo vessel, even though the experience of the operation of ships that received the addition of shipping on some lines, shipping is too small and on others can be large [12], which means that the power propulsion is too small or too large.

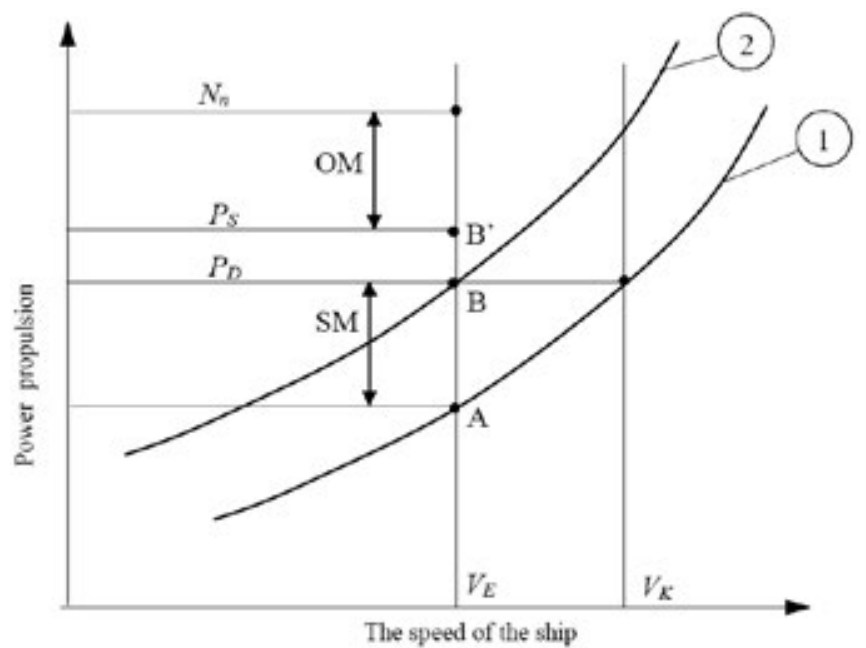

Fig. 2 Determination of propulsion power and ship service speed $V_{E}$ based on model tests of resistance and sea margin (SM) Explanations:

$N_{n}$ - nominal engine power, $P_{s}$ - power to the shaft line (point $\left.B^{\prime}\right), P_{D}$ - power delivered to the propeller, $O M$ - assumed power reserve (standard 10\%), SM - the sea margin (standard 15\%), $B$ ' $B$ - losses resulting from the performance shafting, $B-$ design operating point of the propeller, $A$ - the operating point of the propeller on the calm water, clean hull, $V_{K}$-speed contract, $V_{f}$-projected service speed,

(1) - the characteristics of the power propulsion in calm water, clean hull,

(2) - the characteristics of the power propulsion with the sea margin

\section{THE TERM POWER PROPULSION}

Power propulsion during the ship design

According to the generally accepted methodology of ship design, power propulsion is equal to [4]:

$$
P_{g}=\frac{P_{E}}{\eta}
$$


where:

$\mathrm{P}_{\mathrm{B}}$ - power to the motor coupling the main propulsion:

$$
P_{B}=0.9 \cdot N_{n}
$$

$\mathrm{N}_{\mathrm{n}}$ - nominal power of the drive motor (Fig. 2),

$\mathrm{P}_{\mathrm{E}}$ - towing power:

$$
P_{E}=V \cdot R_{C}
$$

$\mathrm{V}$ - speed of the vessel,

$\mathrm{R}_{\mathrm{C}}$ - the total resistance of the vessel,

$\mathrm{H}$ - overall propulsion efficiency:

$$
\eta=\eta_{G} \cdot \eta_{S} \cdot \eta_{H T} \cdot \eta_{0} \cdot \eta_{R T}
$$

$\eta_{\mathrm{G}}-$ gear efficiency, if used,

$\eta_{\mathrm{s}}$ - shaft efficiency,

$\eta_{\mathrm{HT}}-$ hull efficiency:

$$
\eta_{H T}=\frac{1-t}{1-w_{T}}
$$

$\mathrm{t}$ - thrust deduction faction,

$\mathrm{w}_{\mathrm{T}}$ - wake coefficient,

$\eta_{0}$ - propeller efficiency (without the hull of the vessel),

$\eta_{\mathrm{RT}}-$ rotative efficiency.

At the preliminary stage of ship design, there are known: the service speed $V_{E}$, the total resistance $R_{C}$, the efficiency $\eta_{0}$ screws and coefficients $\eta_{H T}$ and $\eta_{R T}$, so power propulsion $P_{B}$ (or motor nominal power $N_{n}$ ) is calculated with a very approximate formulas:

- method of Silverleaf-Dowson [8]:

$$
\begin{gathered}
P_{E}=1.684 \cdot 10^{-3} \cdot \lambda \cdot k_{V} \cdot D^{2 / 3} \cdot w^{3} \\
\lambda=0.85+0.00185 \cdot(10-0.0328 \cdot L) \\
w=(3.28 \cdot L)^{1 / 2} \cdot\left(1.7-1.4 \cdot c_{B}\right) \\
k_{V}=\left(\frac{V}{w}\right)^{4.16 \frac{V}{w}}
\end{gathered}
$$

where:

$D$ - displacement of the ship [t],

$\mathrm{L}-$ length of the ship [m],

$\mathrm{V}$ - speed of the ship [w],

$\mathrm{C}_{\mathrm{B}}$ - block coefficient of hull [-],

$\mathrm{P}_{\mathrm{E}}$ - towing power [KM],
- method of Watson [8]:

$$
P_{E}=\frac{V^{3} \cdot D^{2 / 3}}{c_{A}}
$$

$$
c_{A}=\frac{15000-n \cdot \sqrt{L}}{40-\frac{L}{200}+400 \cdot\left(c_{B}+0.5 \cdot \frac{V}{\sqrt{L}}-1\right)^{2}-12 \cdot c_{B}}
$$

where:

$D$ - displacement of the ship [t],

$\mathrm{C}_{\mathrm{B}}$ - block coefficient of hull [-],

$\mathrm{L}$ - length of the ship [ $\mathrm{ft}$ ],

$\mathrm{V}$ - speed of the ship [w],

$\mathrm{N}$ - revolutions of propeller [rev/ $\mathrm{min}$ ]

$\mathrm{P}_{\mathrm{E}}$ - towing power [KM].

Although in the above formulas power towing $P_{E}$ depends only on the parameters of a ship, used in these formulas ship speed is the speed in calm water and not service that reaches the ship in real weather conditions. The above formulas are applied to the preliminary design stage (p. 1 Fig. 1). Only after signing the contract (p. 2 Fig. 1) are carried out model tests of resistance and propulsion power in calm water (characteristic 1 in Fig. 2, and then using the sea margin SM approximate the estimated speed is service $V_{E}$ (characteristics 2 Fig. 2). this estimate how service speed is not the actual service speed reached by the ship in real weather conditions.

While the power propulsion of this method is the power needed to achieve the contracted speed $V_{\mathrm{K}}$ calm water, Fig. 2.

With this approach, it is not known what power should have a motor, the ship could reach the established service speed in real weather conditions occurring in a given shipping line.

\section{The total resistance of the ship on the shipping line}

To be able to determine what must be the power propulsion, at which the ship can achieve at a given shipping line established service speed must know the average total resistance.

The ship can sail at different shipping lines that run through the various reservoirs. For these areas there are weather events, mainly wind and wave (Fig. 3), for which numerical values of the parameters of waves and winds occur with varying probability. It is also likely to vary depending on the season. Therefore, the total resistance of the vessel will be the size of a random statistical average value of the assumed probability of exceeding.

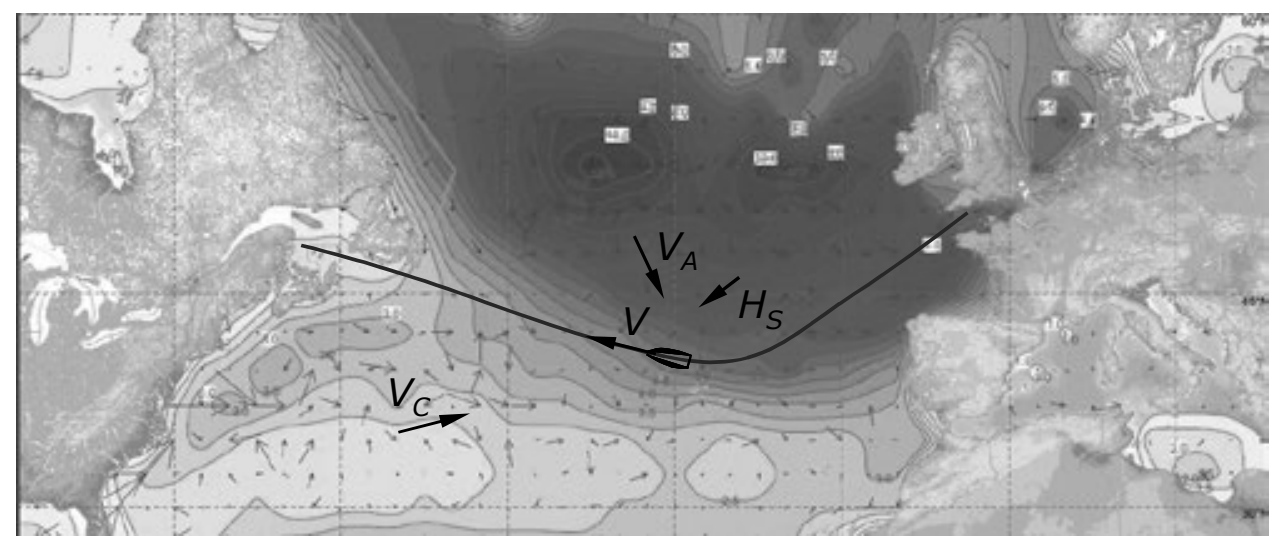

Fig. 3 Example of shipping route and directions of impact on the marine environment of the ship 
The total resistance of the ship in real weather conditions is equal to:

$$
R_{C}=R+\Delta R
$$

where:

$R$ - resistance of a ship in calm water,

$\Delta R$ - additional ship resistance coming from the impact of wind and wave and steering devices:

$$
\Delta R=R_{x d}+R_{x C}+R_{x W}+R_{x R}
$$

$R_{x A}$ - additional resistance from the wind,

$R_{x c}$ - additional resistance from the sea surface currents,

$\mathrm{R}_{\mathrm{xW}}$ - additional resistance from the waves,

$\mathrm{R}_{\mathrm{XR}}$ - additional resistance from eg. steering gear retaining ship on a given course (interference of the course are also caused by the impact of wind and wave).

In [12] was presented developed a mathematical model of the total resistance of the vessel during the voyage on the set of the shipping line in the actual weather conditions. The results of calculation of the total resistance for ships built at the Szczecin Shipyard [12] on the selected shipping lines shown in Fig. 4.
The mathematical model and a computer program [12] to calculate the total resistance cannot be used for preliminary ship design, because it requires knowledge of many parameters of the designed ship, which at this stage (preliminary) are not yet known. It may, however, be used to model the total resistance and power propulsion, based only on the basic geometrical parameters which will allow you to use it at the stage of preliminary design.

\section{THE CONCEPT MODEL POWER PROPULSION, USEFUL AT THE STAGE OF PRELIMINARY DESIGN}

Assumptions to build the model propulsion power for the established service speed

The total resistance of the vessel consists of a resistance of water (including the surface sea current), an additional resistance to wind, wave and the fin of the rudder which is tilted to maintain the desired course. Because during the cruise, the ship may affect the wind, waves and ocean currents (Fig. 3) at any angle to the direction of movement of the ship, the ship will flow from a specific angle drift. In this situation, for each component of total resistance must be calculated three components: longitudinal force, lateral and moment rotating ship - Fig. 5 .
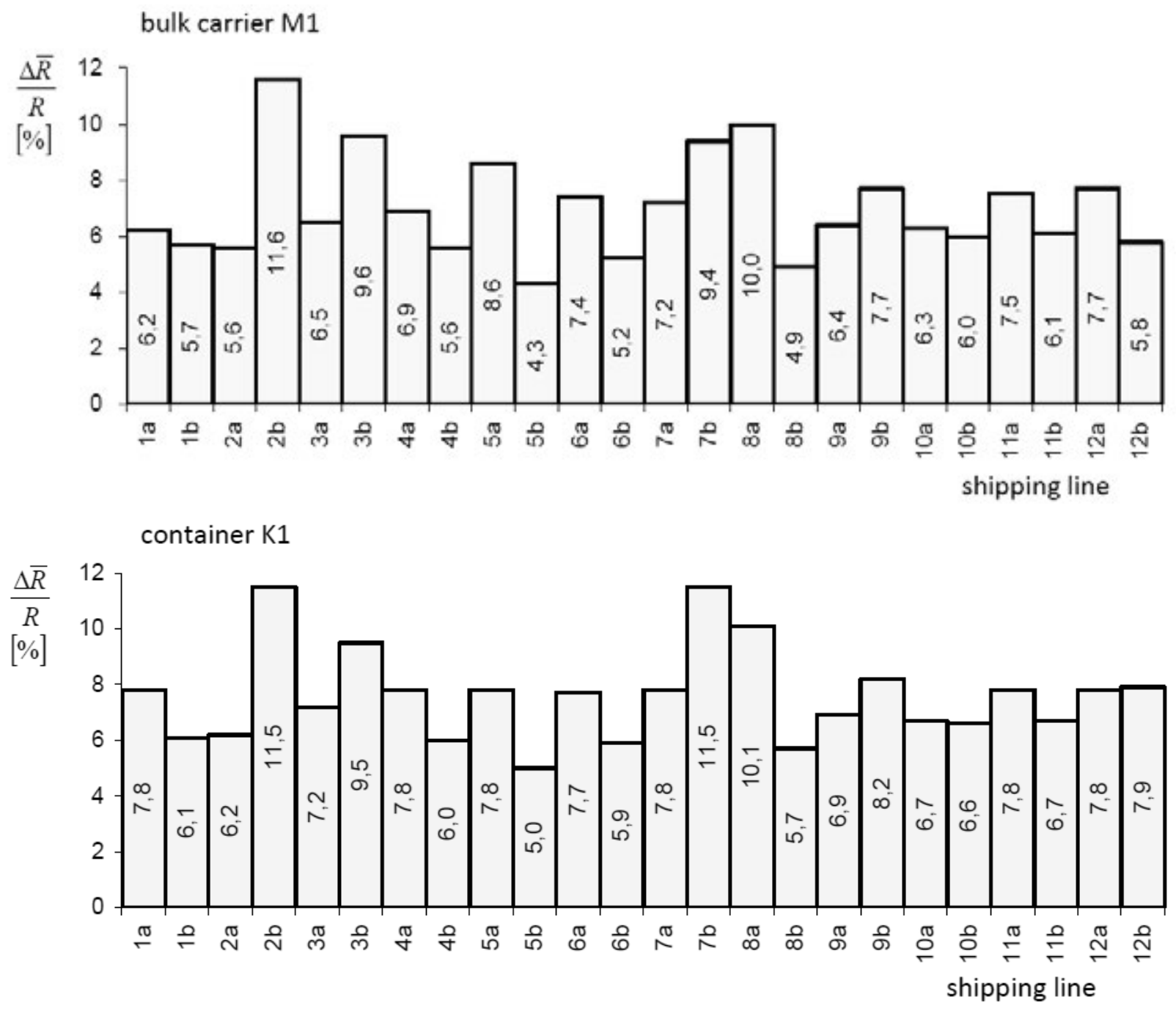

Fig. 4 Increase of additional resistance $\Delta \bar{R}$ for two exemplary ship depending on the shipping line ( $R$ - resistance in calm water) 


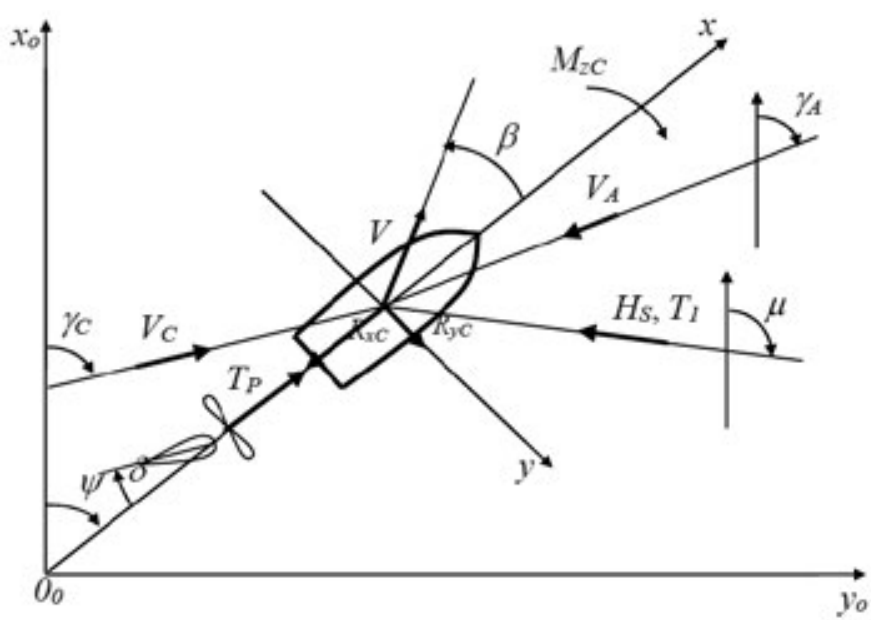

Fig. 5 The components of the total resistance of the vessel (water, wind, waves) $R_{x c}, R_{y c}, M_{z c}$, velocity $V$ and drift angle $B$ of the ship, $T_{p}$ thrust propeller, rudder angle $\delta$

Geometric parameters of the ship on the stage of preliminary design

To fully developed model of resistance and power propulsion could be useful at the stage of preliminary design must be subject, in addition to weather parameters occurring on the shipping lines, only the basic geometrical parameters of the ship's hull, which are:

- length $\mathrm{L}$,

- breadth B,

- draught T,

- height side $H$,

- displacement $\nabla$,

- block coefficient $C_{B}$,

- waterline coefficient $C_{W P}$,

- longitudinal prismatic coefficient $C_{p}$, and optionally ratios main dimensions, for example L/B, B/T.

The search for a function approximating the components of total resistance and power propulsion

For the components of total resistance and power propulsion must find features approximation depends only on the basic geometric parameters of the ship referred to in section 4.2. Due to the form of the final model, the approximation functions must be characterized by:

- high accuracy,

- simplicity of function approximation.

The search function approximation started by formulating appropriate working hypothesis and then tested various functions to the accuracy of the approximation achieved established. The final form of the function approximation and its statistical tests were carried out on the basis of ships built database containing all the necessary technical parameters. Developed approximated function was then tested essentially based on second base ships built at the Szczecin Shipyard, for which there is full documentation together with the results of pool model tests and measurements carried out for ships built on the kind of measurement. Full description of the development of a mathematical model of service speed of the ship, useful for preliminary design is contained in [13].

\section{FINAL CONCLUSIONS}

1. During the design of the ship it is very important preliminary step in which decisions are the basic design decisions with very little knowledge of the planned ship.

2. To assess the excellence of the emerging ship design they use different measures - recently more and more often these are measures of economic and environmental (emissions).

3. One of the most important parameters assumed by the shipowner, is its speed, which also occurs in various measures of quality assessment of the project. For this speed should be determined by the power propulsion.

4. Power propulsion design stage is pre-determined with very rough patterns - usually a power propulsion in calm water.

5. There is no pattern (methods) of calculating power propulsion for the service speed in real weather conditions, suitable for use at the stage of preliminary design.

\section{REFERENCES}

[1] T. Abramowski, Elementy multidyscyplinarnej optymalizacji wskaźników techniczno-ekonomicznych we wstępnym projektowaniu współbieżnym statków transportowych, Szczecin: Wydawnictwo Uczelniane Zachodniopomorskiego Uniwersytetu Technologicznego w Szczecinie, 2011.

[2] W. Chądzyński, „Elementy współczesnej metodyki projektowania obiektów pływających", Prace Naukowe Politechniki Szczecińskiej. Katedra Oceanotechniki i Projektowania Systemów Morskich, no. 563, Szczecin: Wydawnictwo Uczelniane Politechniki Szczecińskiej, 2001.

[3] Consideration of the energy efficiency design index for new ships, GHG-WG 2/2/7, 2009.

[4] J. Dudziak, „Teoria okrętu”, Gdańsk: Wydawnictwo Morskie, 1988.

[5] G. Gabrielli and T.V. Karman, "What Price Speed", Mechanical Engineering, vol. 10, no. 72, 1950, pp. 775 $-781$.

[6] S. Harries, C. Abt, J. Heimann and K. Hochkirch, "Advanced Design of Container Carriers for Improved Transport Efficiency", RINA Conf. Design \& Operation of Container Ships, London, United Kingdom, 2006, [Online]. Available: https://www.researchgate.net/ profile/Karsten_Hochkirch/publication

[7] Interim Guidelines on the Method of Calculation of the Energy Efficiency Design Index for New Ship's, MEPC.1/Circ.681, 2009.

[8] J.P. Michalski, Podstawy teorii projektowania okrętów, Gdańsk: Wydawnictwo Politechniki Gdańskiej, 2013.

[9] M. Stopford, Maritime Economics, Taylor\&Francis eLibrary, 2003.

[10] J. Yong, R. Smith, L. Hatano and S. Hillmansen, "What Price Speed - Revisited”, Ingenia, vol. 22, 2005, pp. 46 -51 .

[11] Y. Ozaki, J. Larkin, K. Tikka and K. Michel, "An Evaluation of the Energy Efficiency Design Index (EEDI) Baseline for Tankers, Containership and LNG Carriers", Technical report, ABS/Herbert Engineering, February 
2010, Sname/Marine Board Symposium, 2010-02$16 / 17$.

[12] K. Żelazny, „Numeryczne prognozowanie średniej długoterminowej prędkości eksploatacyjnej statku transportowego", Ph.D. dissertation, Faculty of Maritime Technology and Transport, West Pomeranian of Technology in Szczecin, Szczecin, 2005.

prof. dr hab. inż. Tadeusz Szelangiewicz,

dr hab. inż. Katarzyna Żelazny, prof. AM

Maritime University of Szczecin, Faculty of Navigation,

Wały Chrobrego 1-2, 70-500 Szczecin, POLAND

e-mail: t.szelangiewicz@am.szczecin.pl

k.zelazny@am.szczecin.pl
[13] K. Żelazny, Metoda wyznaczania prędkości eksploatacyjnej przydatna w projektowaniu wstępnym statków transportowych w statystycznych warunkach pogodowych występujqcych na liniach żeglugowych, Szczecin: Wydawnictwo Uczelniane Zachodniopomorskiego Uniwersytetu Technologicznego w Szczecinie, 2015. 